\title{
Engagement of Human PECAM-1 (CD31) on Human Endothelial Cells Increases Intracellular Calcium Ion Concentration and Stimulates Prostacyclin Release
}

\author{
Indira Gurubhagavatula, Yassine Amrani, Domenico Pratico, ${ }^{\star}$ Frederick L. Ruberg, Steven M. Albelda, \\ and Reynold A. Panettieri, Jr. \\ Pulmonary and Critical Care Division and *Center for Experimental Therapeutics, University of Pennsylvania Medical Center, \\ Philadelphia, Pennsylvania 19104
}

\begin{abstract}
Platelet-endothelial cell adhesion molecule-1 (PECAM-1) is a member of the immunoglobulin superfamily that plays a role in a number of endothelial cell (EC) functions including migration, angiogenesis, and transmigration of leukocytes across endothelium. We postulated that one way PECAM-1 might exert its effects was by regulating intracellular EC levels of calcium. Using single-cell fluorometry, we found that engagement of PECAM-1 by mAbs induced a slow but sustained increase in intracellular calcium, both in EC and in an adherent PECAM-1-transfected cell line that models endothelium. Generation of this signal was specific for certain anti-PECAM-1 antibodies, required the presence of the cytoplasmic domain, depended on extracellular calcium and on tyrosine phosphorylation, but did not require crosslinking; in fact, calcium increases were stimulated by certain Fab fragments. Activation of EC by PECAM-1 also caused a time-dependent increase in prostacyclin release. Given the importance of intracellular calcium and prostacyclin release as signaling molecules, engagement of PECAM-1 during cell-cell interactions may alter a number of EC functions including secretion of vasoactive mediators. (J. Clin. Invest. 1998. 101:212-222.) Key words: cell adhesion molecules • cell signaling • inflammation • antibody cross-linking • cell-cell interactions
\end{abstract}

\section{Introduction}

Several key endothelial cell $(\mathrm{EC})^{1}$ functions are regulated by changes in intracellular levels of calcium $\left(\left[\mathrm{Ca}^{2+}\right]_{i}\right)(1)$. Elevations of $\left[\mathrm{Ca}^{2+}\right]_{i}$ have been shown to activate $\mathrm{Ca}^{2+}$-dependent enzymes in ECs that are important in maintaining vascular

I. Gurubhagavatula and Y. Amrani contributed equally to this manuscript.

Address correspondence to Dr. Reynold A. Panettieri, University of Pennsylvania Medical Center, Pulmonary and Critical Care Division, Rm. 805 East Gates Bldg., HUP/3400 Spruce St., Philadelphia, PA 19104-4283. Phone: 215-349-5480; FAX: 215-349-5172; E-mail: rap@mail.med.upenn.edu

Received for publication 31 March 1997 and accepted in revised form 16 October 1997.

1. Abbreviations used in this paper: $\left[\mathrm{Ca}^{2+}\right]_{\mathrm{i}}$, intracellular calcium; $\mathrm{EC}$, endothelial cells; HUVEC, human umbilical vein endothelial cells; PECAM-1, platelet-endothelial cell adhesion molecule-1; $\mathrm{PGl}_{2}$, prostacyclin.

J. Clin. Invest.

(C) The American Society for Clinical Investigation, Inc. 0021-9738/98/01/0212/11 \$2.00

Volume 101, Number 1, January 1998, 212-222

http://www.jci.org tone (2). These include phospholipase $A_{2}$ and nitric oxide synthase that lead to synthesis and release of mediators such as prostacyclin $\left(\mathrm{PGl}_{2}\right)$ and endothelium-derived relaxing factor. Increases in $\mathrm{Ca}^{2+}$ levels have also been implicated in the secretion of EC granules (Weibel-Palade bodies) leading to the release of von Willebrand factor and P-selectin (3). $\left[\mathrm{Ca}^{2+}\right]_{\mathrm{i}}$ also plays a major role in determining the shape of adherent cells through regulation of the cytoskeleton (4) and thus affects permeability (5-8). Finally, leukocyte transendothelial migration also depends on increases in cytosolic $\mathrm{Ca}^{2+}$ levels (9).

One EC adhesion molecule that has been implicated in migration (10), angiogenesis (11), permeability (12), and the transmigration of neutrophils in vitro (13-15) and in vivo (16) is platelet-endothelial cell adhesion molecule-1 (PECAM-1/ CD31). PECAM-1 is a member of the immunoglobulin (Ig) superfamily with six Ig-like loops expressed at endothelial intercellular junctions, as well as on platelets, monocytes, neutrophils, and subsets of lymphocytes (17). Although originally defined as a cell-cell adhesion molecule, a number of studies suggest a role for PECAM-1 in cellular signaling, specifically in the activation of $\beta 1$ and $\beta 2$ integrins on leukocytes (for review see reference 18). It is not currently known if cell-cell adhesion, integrin activation, or some other property of PECAM-1 is responsible for the ability of this molecule to regulate EC function or the movement of neutrophils through endothelial barriers.

A previously unexplored mechanism by which PECAM-1 may exert its effects on ECs is by regulating $\left[\mathrm{Ca}^{2+}\right]_{\mathrm{i}}$. Deaglio et al. (19) reported recently that cross-linking an unidentified CD38 ligand identified by the mAb Moon- 1 on the surface of leukemic $\mathrm{T}$ cells induced an increase in $\left[\mathrm{Ca}^{2+}\right]_{\mathrm{i}}$ similar to that seen by engagement of the $\mathrm{T}$ cell receptor. Although the identity of this $120-\mathrm{kD}$ antigen was not known at the time of publication, subsequent work showed that the Moon-1 antigen is, in fact, identical to PECAM-1/CD31 (Albelda, S.M., unpublished observations). This observation suggests the possibility that engagement of PECAM-1 on ECs may be important in the regulation of $\left[\mathrm{Ca}^{2+}\right]_{\mathrm{i}}$ and therefore effect a number of important EC activities such as secretion, permeability, and neutrophil transmigration.

To test this hypothesis, we measured $\left[\mathrm{Ca}^{2+}\right]_{i}$ in ECs after engagement of PECAM-1 with monoclonal anti-PECAM-1 antibodies. Using fura-2-loaded human umbilical vein ECs (HUVEC), we found that engagement of PECAM-1 evoked a sustained increase in cytosolic free $\mathrm{Ca}^{2+}$, quite different in character from the increase induced by thrombin. To dissect mechanisms regulating PECAM-1 effects on $\mathrm{Ca}^{2+}$ mobilization, we studied a cultured mesothelioma cell line (REN) in which human PECAM-1 cDNA had been transfected permanently (REN-HP cells). In REN-HP cells, but not the untransfected REN cells, PECAM-1 engagement with intact antiPECAM-1 mAbs or Fab fragments also evoked an increase in $\left[\mathrm{Ca}^{2+}\right]_{\mathrm{i}}$ in a manner similar to that seen in ECs. This signal was 
induced by some, but not all, anti-PECAM-1 mAbs and depended on the presence of an intact cytoplasmic tail. Finally, we assessed one easily measurable $\mathrm{Ca}^{2+}$-dependent functional outcome of PECAM-1 engagement, and found that antiPECAM-1 antibody induced the release of $\mathrm{PGl}_{2}$. Thus, PECAM-1 engagement on the surface of ECs transmits a signal through its cytoplasmic domain that induces a sustained increase in $\left[\mathrm{Ca}^{2+}\right]_{\mathrm{i}}$ accompanied by $\mathrm{PGl}_{2}$ release in the supernatant. We speculate that this signal may also play an important role in modulation of EC functions in health and disease.

\section{Methods}

$m A b$ production and purification. The antibodies used included W6/ 32, a mAb against the human MHC-I common heavy chain (American Type Culture Collection, Rockville, MD), and 4G6, a mAb specific for the sixth extracellular domain of human PECAM-1 (20). Purified antibodies were obtained by protein $\mathrm{G}$ affinity chromatography of supernatants from hybridomas secreting these mAbs. Other antihuman PECAM-1 mAbs and all the Fabs were provided by Centocor (generously donated by Dr. Marian Nakada) and included mAb 35, 37, 62, and 66, as well as Fab fragments of mAb 4G6. The Moon-1 antibody was provided by Dr. F. Malavasi (Torino, Italy). All Fabs used in the study were evaluated by SDS-PAGE to ensure lack of contaminating intact antibody.

Epitope mapping. Epitope mapping was conducted as described previously in detail (20) and took advantage of the fact that the human mAbs do not crossreact with mouse PECAM-1. Using mouse PECAM-1 as a backbone, human/mouse chimeric molecules that contained either Ig-like domains 1 or 2 from human PECAM-1 were constructed and transfected into COS cells growing on glass coverslips using the calcium phosphate method described previously (21). After $48 \mathrm{~h}$, immunofluorescence staining was performed with the antibodies used in our study, including all Centocor antibodies and the Moon- 1 antibody. They were examined by fluorescence microscopy and staining was compared with background staining in untransfected COS cells and to COS cells transfected with full-length human PECAM-1. Staining patterns were easily classified as either positive or negative for each test antibody. Epitope mapping of 4G6 to the 6th Ig-like domain has been described previously (20).

Cells. HUVEC were purchased from Clonetics (San Diego, CA) and cultured in medium 199 (Mediatech Inc., Herndon, VA) containing $15 \%$ FBS, $75-100 \mu \mathrm{g} / \mathrm{ml}$ EC growth factor (Clonetics), $100 \mu \mathrm{g} / \mathrm{ml}$ heparin, and $2 \mathrm{mM}$ L-glutamine (22). REN cells are a human malignant mesothelioma cell line previously isolated and characterized in our laboratory (23). These cells grow in RPMI media supplemented with $10 \%$ FBS with penicillin/streptomycin and $2 \mathrm{mM}$ L-glutamine.

REN cells were transfected with human PECAM-1 subcloned into the pcDNA-Neo vector (Invitrogen, San Diego, CA) using lipofectin. Positive clones were selected in G418 (GIBCO BRL, Grand Island, NY) as described previously $(21,24)$. A mutant construct of PECAM-1 which lacked the cytoplasmic tail $(25,26)$ was also transfected into REN cells using the same approach. Expression of surface PECAM-1 was confirmed by flow cytometry (see flow cytometry in Methods).

Cell preparation. Round 15-mm glass coverslips were coated for $1 \mathrm{~h}$ with $10 \mu \mathrm{g} / \mathrm{ml}$ fibronectin in a volume of $70 \mu \mathrm{l}$ per coverslip. They were placed in six-well tissue culture plates and were then seeded for $48 \mathrm{~h}$ at 150,000 cells/well in a final volume of $4 \mathrm{ml}$ of culture media. At the time they were used, the cells (either HUVEC or REN cells) were confluent or nearly confluent.

Measurement of $\left[\mathrm{Ca}^{2+}\right]$ i. $\mathrm{Ca}^{2+}$ measurements were conducted as described previously (27). Cells were washed with loading media (14.8 g M199, $6.0 \mathrm{~g}$ Hepes, $1.8 \mathrm{~g}$ D-glucose, $1.0 \mathrm{~g}$ bovine serum albumin, $\mathrm{pH} 7.4$, in 1 liter), then were incubated with $3.5 \mu \mathrm{M}$ acetomethyl ester of fura-2 (fura-2/AM, Molecular Probes Inc., Eugene, OR) in loading media for $45 \mathrm{~min}$ at $37^{\circ} \mathrm{C}$. They were then washed in Hepesbuffered solution (Hepes $6.0 \mathrm{~g}, \mathrm{NaCl} 7.2 \mathrm{~g}$, D-glucose $2.7 \mathrm{~g}, \mathrm{CaCl}_{2} 2.0$ mol, $\mathrm{KCl} 5.0 \mathrm{~mol}, \mathrm{MgCl}_{2} 0.254 \mathrm{~mol}, \mathrm{NaH}_{2} \mathrm{PO}_{4} 0.4 \mathrm{~mol}$, final $\mathrm{pH}$ 7.4). Cells were placed in a temperature-controlled chamber (volume of $1 \mathrm{ml}$ ) on a Nikon inverted microscope (Diaphot) and imaged at a magnification of 40 under oil, using a fluorescence objective lens. A 75-W xenon lamp and a fura-2 dichroic mirror (Chroma Technology, Brattleboro, VT) were used to emit excitation light at wavelengths alternating between 340 and $380 \mathrm{~nm}$. Reflected light passed through a 510-nm filter and through an image-intensifying CCD camera (Hamamatsu Phototonics, Hamamatsu City, Japan). A video A to D board (Maatrox) was used to digitize the images. A cursor was used to select single cells for cytosolic calcium concentration recordings; analysis of regions thus selected was done using the Image-2/AT/fluor program (Universal Imaging Corp., West Chester, PA). The ratio of fluorescence at $340 \mathrm{~nm}$ to that at $380 \mathrm{~nm}(\mathrm{R})$ was converted to calcium concentration using the technique described by Grynkiewicz et al. (28). $R_{\max }$ and $R_{\min }$ were determined using ionomycin $(20 \mu \mathrm{M})$ with calcium $(12 \mathrm{mM})$, or a stoichiometric excess of EGTA, respectively. Thus, $R_{\max }$ represented the ratio of $340 \mathrm{~nm} / 380 \mathrm{~nm}$ signal under saturating conditions of calcium, while $R_{\text {min }}$ represented the same ratio in the absence of calcium. Values used for calibration included $\mathrm{R}_{\max }=3.9, \mathrm{R}_{\text {min }}=0.2, K_{\mathrm{d}}=224 \mathrm{nM}$, and $\mathrm{f} 380_{\text {min }} / \mathrm{f} 380_{\text {max }}$ (ratio of fluorescence at high calcium to that at low calcium) $=5$.

After a short period of equilibration, $200 \mu \mathrm{g} / \mathrm{ml}$ of $\mathrm{mAb}$ or $\mathrm{Fab}$ fragment was added directly to the chamber containing cells. Because of the $1 \mathrm{ml}$ of buffer in the chamber, the final concentration of $\mathrm{mAb}$ was $\sim 20 \mu \mathrm{g} / \mathrm{ml}$. Preliminary experiments showed that this concentration of 4G6 gave the maximal response. Accordingly, all subsequent experiments were conducted with this concentration of $\mathrm{mAb}$. In some experiments, cells were pretreated with genistein, an inhibitor of protein tyrosine kinases, and then stimulated with $4 \mathrm{G} 6$ or thrombin. The concentration of genistein and the incubation time are those that maximally inhibit protein tyrosine kinases (see reference 38). A minimum of 10 cells was selected for analysis and at least two cell lines were tested for each condition. Statistical comparisons between average basal and average peak levels were made using the Student's $t$ test.

Flow cytometry. HUVEC, REN cells, and REN cells transfected with human PECAM-1 constructs (REN-HP, REN-CDM2) were removed from confluent T25 flasks with $1 \mathrm{ml}$ of $1 \times$ trypsin. They were washed in $1 \times$ PBS and treated with anti-PECAM-1 mAb at a concentration of $5-25 \mu \mathrm{g} / \mathrm{ml}$ for $1 \mathrm{~h}$ at $4^{\circ} \mathrm{C}$. The primary antibody was removed and the cells were then washed once in $1 \times$ PBS and placed in FITC-conjugated secondary antibody at a 1:200 dilution for $1 \mathrm{~h}$ at $4^{\circ} \mathrm{C}$. The cells were again washed in $1 \times$ PBS after secondary antibody was removed and resuspended in $1 \times$ PBS. Flow cytometry was done with an Ortho cytofluorograph cell sorter equipped with a 2150 data handling system (model 50H; Ortho Instruments, Westwood, MA). Fluorescence intensity was expressed as arbitrary units on a linear scale.

$\mathrm{PGl}_{2}$ measurement. $\mathrm{PGl}_{2}$ was measured in the cell culture media as its stable metabolite 6-keto $\mathrm{PGF}_{1 \alpha}$ by a stable isotope gas chromatography/mass spectrometry assay, as described previously (29). Briefly, a known amount of internal standard, $\left[{ }^{2} \mathrm{H}_{4}\right] 6-k e t o \mathrm{PGF}_{1 \alpha}$, was added to the samples. After forming the methoxyamine derivatives, the samples were acidified ( $\mathrm{pH} 3.0$ ) and applied to a 100-mg octadecylsilyl solid-phase extraction column (Alltech Associates Inc., Deerfield, IL). The elutions were dried under a stream of nitrogen, then derivatized as pentafluorobenzyl esters. This reaction mixture was dried under nitrogen and applied to a TLC plate (LK6D, 60A Silica Gel Plates; Whatman Inc., Clifton, NJ). The mobile phase was $80 \%$ ethyl acetate and $20 \%$ heptane. The extractions were dried and the trimethylsilyl ether derviatives were formed. The reaction mixture was dried under nitrogen, the sample redissolved in dodecane, and analyzed by a gas chromatograph/mass spectrometer (model MO800; Fison, Los Angeles, CA). The temperature program was 190 $320^{\circ} \mathrm{C}$ at $20^{\circ} \mathrm{C} / \mathrm{min}$. The ions monitored were $\mathrm{m} / \mathrm{z} 614$ for 6 -keto $\mathrm{PGF}_{1 \alpha}$ and $m / z 618$ for $\left[{ }^{2} \mathrm{H}_{4}\right] 6-$ keto $\mathrm{PGF}_{1 \alpha}$. 


\section{Results}

Stimulation of human PECAM-1 with mAb $4 G 6$ increases $\left[\mathrm{Ca}^{2+}\right]_{i} H U V E C$. To determine whether engagement of PECAM-1 on HUVEC evokes an increase in $\left[\mathrm{Ca}^{2+}\right]_{i}$, HUVEC were treated with 4G6, an antibody that reacts with the sixth Ig-like domain on human PECAM-1 (20). Flow cytometry of HUVEC with this antibody showed high level expression (Fig. $1 A$ ). As Fig. $2 A$ shows, treatment of HUVEC with 4G6 resulted in a 1.5-2-fold increase in $\left[\mathrm{Ca}^{2+}\right]_{\mathrm{i}}$ from a basal level of $100-200 \mathrm{nM}$ to a maximum elevation of $150-350 \mathrm{nM}$. These differences were significant $(P<0.01)$. This rise was noted $\sim 1.5-2$ min after addition of 4G6 and was characterized by a slow linear phase of increase in $\left[\mathrm{Ca}^{2+}\right]_{\mathrm{i}}$ followed by a sustained plateau which was reached within 5 min of antibody application. In contrast, treatment of HUVEC with an antibody directed against $\mathrm{MHC}-\mathrm{I}$ at the same concentration did not evoke an increase in $\left[\mathrm{Ca}^{2+}\right]_{\mathrm{i}}$ (Fig. $2 \mathrm{~B}$ ), despite the high level of expression of MHC-I on these cells as revealed by flow cytometry $($ Fig. $1 \mathrm{~B})$. These results indicate that the increase in $\left[\mathrm{Ca}^{2+}\right]_{i}$ induced by $4 \mathrm{G} 6$ is not simply a consequence of the interaction of a surface-binding antibody with HUVEC.

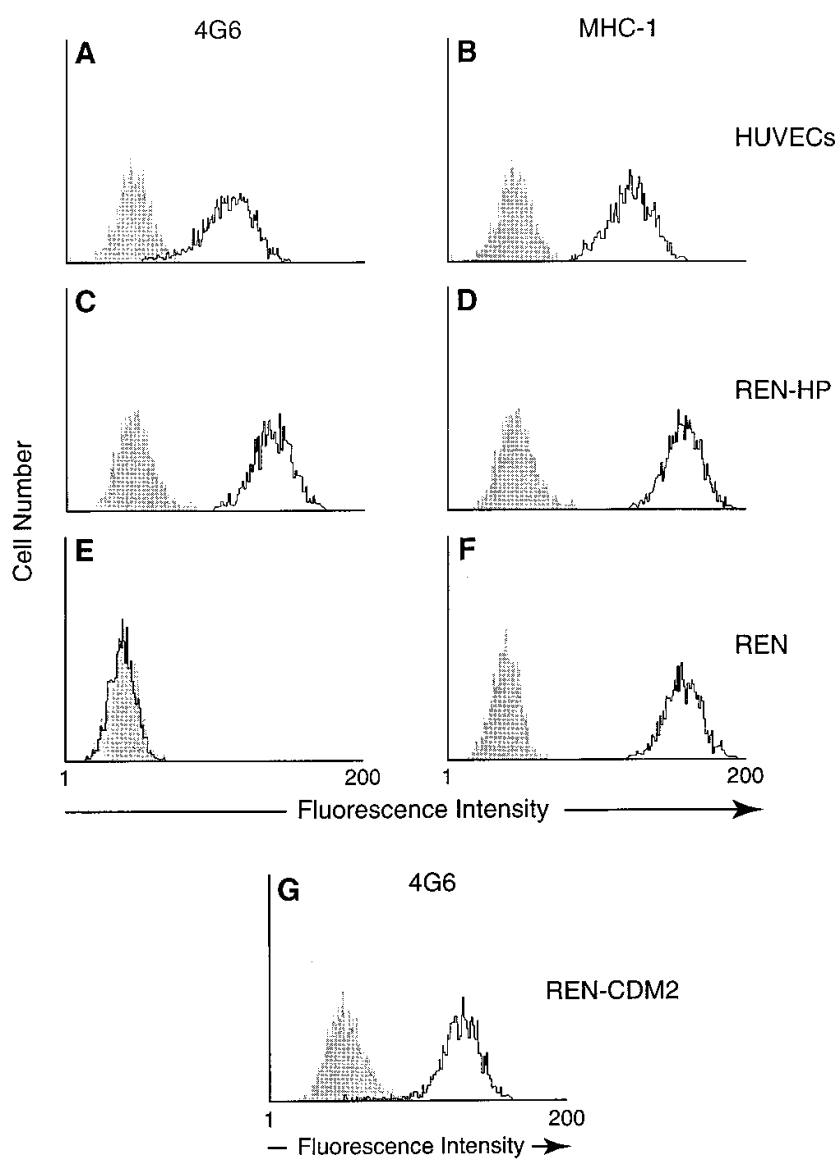

Figure 1. Expression levels of PECAM-1 and MHC-I. Flow cytometry confirms high level expression of PECAM-1 using 4G6, an $\alpha$-PECAM-1 mAb, on HUVEC $(A)$ and REN-HP cells (cells transfected with full-length PECAM-1) $(C)$, but not on untransfected REN cells $(E)$. An $\alpha$-MHC-I mAb binds at high levels on all three cell types ( $B, D$, and $F$, respectively). 4G6 also binds strongly to REN-CDM2 cells $(G)$.
As a positive control, we showed that thrombin $(1 \mathrm{U} / \mathrm{ml})$ also evoked an increase in $\left[\mathrm{Ca}^{2+}\right]_{\mathrm{i}}$. This increase in $\left[\mathrm{Ca}^{2+}\right]_{\mathrm{i}}$ was found to be significantly different from resting level $(P<$ 0.001). Within 3-4 min, the $\left[\mathrm{Ca}^{2+}\right]_{\mathrm{i}}$ declined to a plateau which was close to resting levels. Similar calcium responses to thrombin have been observed in previous reports (30-32). These data suggest that calcium influxes in HUVEC respond to activation of $G$ protein-coupled receptors and that the kinetics of the thrombin responses are quite different from those evoked by engagement of PECAM-1.

$m A b 4 G 6$ increases $\left[\mathrm{Ca}^{2+}\right]_{i}$ in REN cells transfected with human PECAM-1. To further dissect the molecular signaling mechanisms that modulate PECAM-1 calcium responses and to provide additional controls, we tested the ability of antiPECAM-1 antibodies to alter $\left[\mathrm{Ca}^{2+}\right]_{\mathrm{i}}$ in a transformed non-EC line (REN cells) and REN cells that had been transfected with human PECAM-1 (REN-HP cells). Flow cytometry revealed high levels of PECAM-1 expression (similar to those seen on HUVEC) on the REN-HP cells (Fig. $1 C$ ) and lack of expression of PECAM-1 on REN cells (Fig. $1 E$ ). PECAM-1 in REN-HP cells localized to cell-cell junctions in a manner similar to that in HUVEC, as shown in Fig. 3. As shown in Fig. $4 \mathrm{~A}$ (left), engagement of PECAM-1 with 4G6 in REN-HP cells evoked an elevation of $\left[\mathrm{Ca}^{2+}\right]_{\mathrm{i}}$ with similar temporal characteristics and magnitude as in HUVEC (Fig. $2 A$ ). $\left[\mathrm{Ca}^{2+}\right]_{i}$ increased significantly from resting levels of $150-250 \mathrm{nM}$ to a sustained plateau of $280-400 \mathrm{nM}(P<0.001)$. In contrast, 4G6 had no effect on $\left[\mathrm{Ca}^{2+}\right]_{\mathrm{i}}$ in untransfected REN cells (Fig. $4 A$, right), suggesting that the calcium response observed in RENHP cells was due to the cell surface PECAM-1 activation. In addition, as described for HUVEC, anti-MHC-I antibody did not induce calcium responses in REN-HP or in REN cells (Fig. $4 B$ ), despite the high level of MHC-I expression in both cell types (Fig. 1, $D$ and $F$ ). Thrombin $(1 \mathrm{U} / \mathrm{ml})$ was also found to stimulate the increase in $\left[\mathrm{Ca}^{2+}\right]_{\mathrm{i}}$ in both cell types (Fig. $4 \mathrm{C}$ ), demonstrating that PECAM-1 transfection into REN cells did not alter the calcium responsiveness of REN-HP cells to a physiological agonist. Again, the kinetics of the responses to thrombin were quite different from those induced by antiPECAM mAb.

Taken together, these results showed that engagement of human PECAM-1 can induce calcium mobilization in at least two PECAM-1 expressing cells, HUVEC and REN-HP cells.

Increases in $\left[\mathrm{Ca}^{2+}\right]_{i}$ in REN-HP cells and HUVEC induced by $\mathrm{mAb} 4 \mathrm{G6}$ is dependent on calcium from an extracellular source. Receptor-mediated increases in $\left[\mathrm{Ca}^{2+}\right]_{\mathrm{i}}$, in part, consist of two components: release from intracellular stores and influx from across the plasma membrane (35). To determine whether extracellular calcium modulates PECAM-1 calcium responses, we added EGTA $(5 \mathrm{mM})$ to chelate extracellular calcium during the plateau phase of calcium elevation induced by $\mathrm{mAb}$ 4G6 in both HUVEC and REN-HP cells. As shown in Fig. 5, $A$ and $C$, within 1-2 min of application, EGTA (5 mM) abolished the sustained increase in $\left[\mathrm{Ca}^{2+}\right]_{i}$ induced by mAb 4G6 completely. The inhibitory effect of EGTA was found to be dose-dependent for concentrations used between 1 and $5 \mathrm{mM}$ (data not shown). In addition, treatment of REN-HP cells with $4 \mathrm{mM}$ nickel, a calcium influx blocker, completely abolished the sustained increase in $\left[\mathrm{Ca}^{2+}\right]_{\mathrm{i}}$ induced by $4 \mathrm{G} 6$ but had no effect on resting $\left[\mathrm{Ca}^{2+}\right]_{i}$ or on the magnitude of thrombininduced increase in $\left[\mathrm{Ca}^{2+}\right]_{\mathrm{i}}$ (Fig. $5 \mathrm{~B}$, right). In a similar manner, pretreatment of HUVEC with $4 \mathrm{mM}$ nickel abrogated 
A

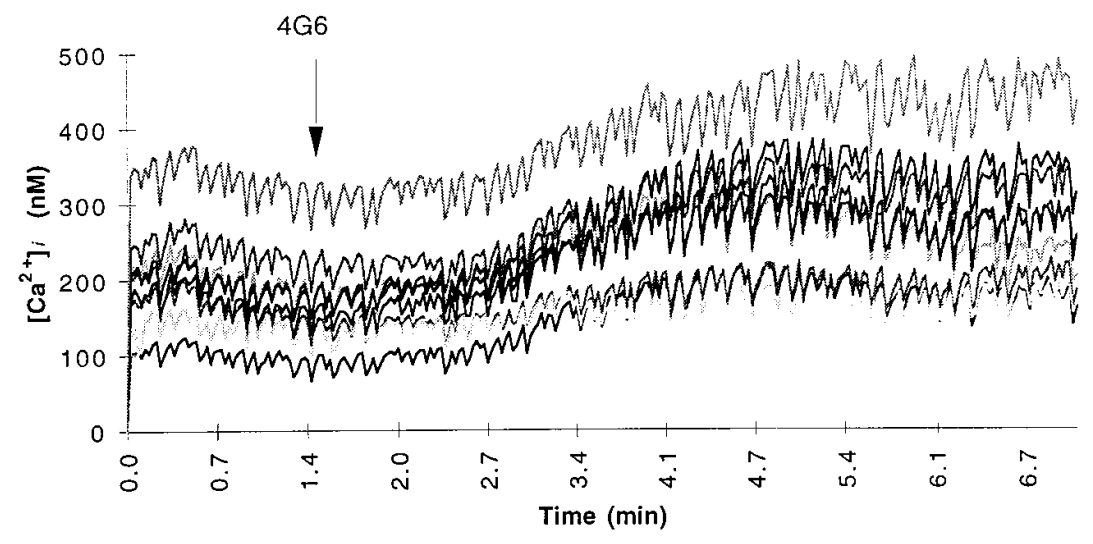

B

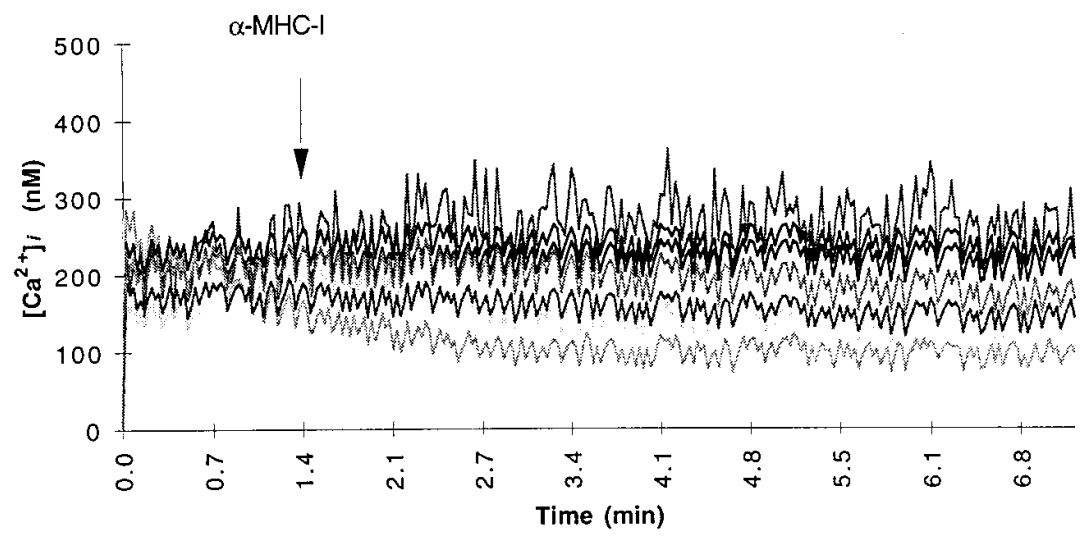

C

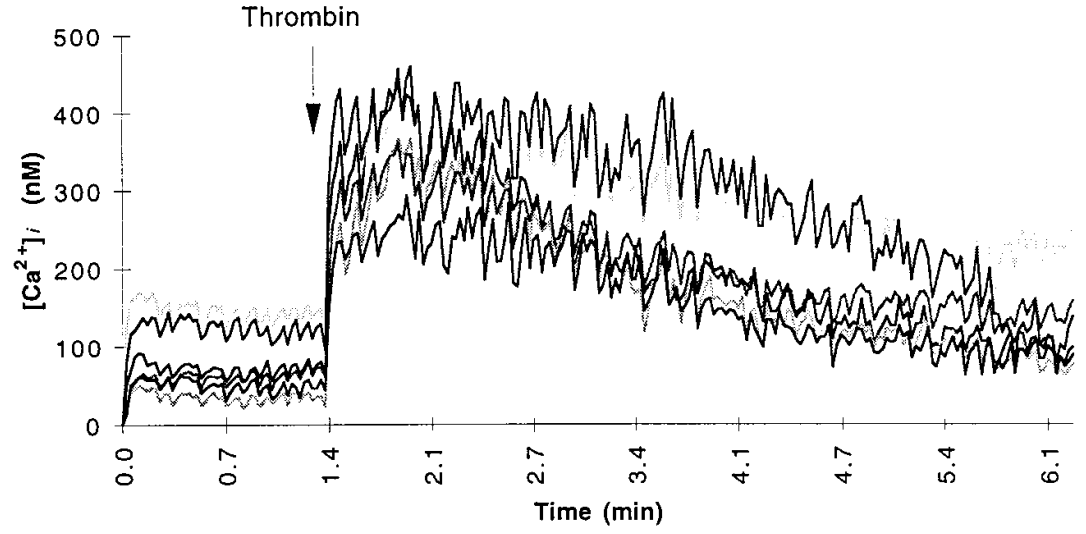

Figure 2. Binding of human PECAM-1 increases $\left[\mathrm{Ca}^{2+}\right]_{i}$ in HUVEC. Fura-2/AMloaded HUVEC were treated with activating antibody or agonist as described in Methods. ( $A$ ) Anti-PECAM-1 mAb 4G6 $(20 \mu \mathrm{g} / \mathrm{ml})$ increases cytosolic free calcium in HUVEC. $(B)$ In contrast, the control $\mathrm{mAb}$ anti-MHC-I has little effect on $\left[\mathrm{Ca}^{2+}\right]_{\mathrm{i} .}(C)$ Thrombin $(1 \mathrm{U} / \mathrm{ml})$ evokes a calcium transient in HUVEC. Each trace represents an individual cell response. A minimum of 10 cells was selected in each experiment, and each experiment was performed in duplicate or quadruplicate.
4G6-induced increases in $\left[\mathrm{Ca}^{2+}\right]_{\mathrm{i}}$ but had no effect on thrombin-induced calcium transients (data not shown). The calcium response induced by thapsigargin, a potent inhibitor of calcium-ATPase, was also unaffected by pretreating cells with nickel (Fig. 5 B, left) when compared to REN-HP cells treated with diluent alone (data not shown). These results suggest that the influx of extracellular calcium is necessary for the sustained response after PECAM-1 activation in REN-HP cells and in HUVEC.

Purified 4G6 Fab also induces a calcium response in REN-HP cells. To examine the importance of receptor cross-linking or clustering versus engagement of PECAM-1 and to exclude a contribution from the $\mathrm{Fc}$ portion of the $\mathrm{mAb}$ in the calcium re- sponses evoked by anti-PECAM-1 antibodies, REN-HP cells or HUVEC (data not shown) were treated with purified 4G6 Fab. As shown in Fig. 6, the purified 4G6 Fab (added to the chamber at a final concentration of $20 \mu \mathrm{g} / \mathrm{ml}$ ) evoked a calcium response that appeared similar in all respects to that obtained with intact $4 \mathrm{G} 6$. This increase in $\left[\mathrm{Ca}^{2+}\right]_{i}$ generally occurred within 2-3 min after addition of the 4G6 Fab from a resting level of 100-200 nM to a sustained level of 200-500 nM $(P<0.001)$. Addition of cross-linking anti-mouse antibodies did not augment the response seen with the Fab (data not shown). During this sustained phase, addition of EGTA also reduced the $\left[\mathrm{Ca}^{2+}\right]_{\mathrm{i}}$ in an exponential manner to values near prestimulation baseline. The effect of purified 4G6 Fab was 
A

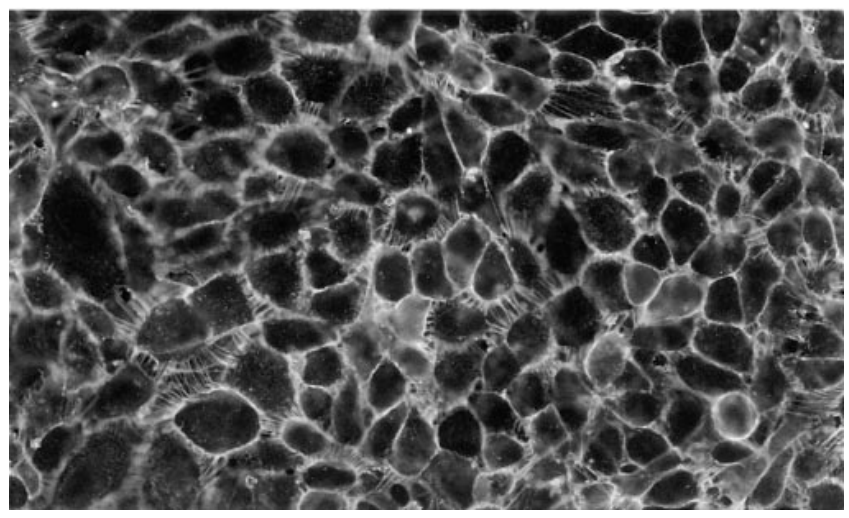

B

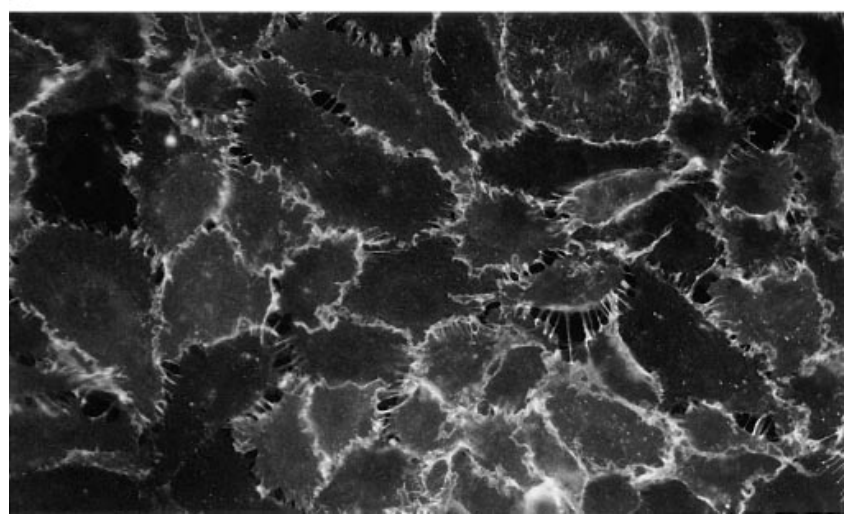

Figure 3. Cell-cell localization of PECAM-1 in transfected REN cells mimics that seen in human ECs. $(A)$ Immunostaining of PECAM-1 with mAb 4G6 on HUVEC reveals the characteristic cell-cell border staining. (B) Immunostaining of PECAM-1 with mAb 4G6 on REN mesothelioma cells transfected with full-length human PECAM-1 (REN-HP cells) shows a similar cell-cell localization.

not due to the presence of contamination by intact 4G6, as determined by immunoblotting after SDS-PAGE chromatography. In addition, Fig. 6 shows that application of the purified 4G6 Fab to REN cells did not produce any increase in cytosolic free calcium.

REN-CDM2 cells which lack the cytoplasmic domain of PECAM-1 fail to experience calcium influx upon PECAM-1 engagement. To determine the role of the cytoplasmic domain in PECAM-1-mediated signal transduction and to provide additional controls, we transfected REN cells with a mutant human PECAM-1 molecule that lacked exons 10-14 (RENCDM2 cells). This construct contains the extracellular and transmembrane portions of PECAM-1 but lacks the cytoplasmic tail of the molecule (25). We verified high surface expression of this mutant PECAM-1 by flow cytometry using 4G6 antibody which still recognized the molecule (Fig. $1 G$ ). Addition of the 4G6 antibody to the REN-CDM2 cells did not produce a calcium signal (Fig. $7 A$ ). In contrast, application of 4G6 to REN cells transfected with intact PECAM-1 (REN-HP) during the same experiment resulted in a clear increase in cytosolic $\left[\mathrm{Ca}^{2+}\right]$ (Fig. 7 B).

Tyrosine phosphorylation is required for PECAM-1-mediated calcium signaling. To determine whether protein tyrosine kinases modulated the mobilization of calcium induced by PE-
CAM-1 engagement, we examined the effect of genistein, a potent protein tyrosine kinase inhibitor, on the calcium response induced by 4G6. As shown in Fig. $7 C$, pretreatment of cells with genistein for $1 \mathrm{~h}$ abolished the subsequent calcium response induced by $4 \mathrm{G} 6(20 \mu \mathrm{g} / \mathrm{ml})$. Interestingly, genistein had no effect on the calcium mobilization induced by thrombin or in cells treated with diluent alone. In parallel experiments, pretreatment of HUVEC with genistein also completely abolished 4G6-induced increases in calcium but did not alter thrombin-induced calcium transients (data not shown). These results show that some part of the signaling pathway involved in calcium mobilization induced by PECAM-1 activation is genistein-sensitive and may require tyrosine phosphorylation.

Anti-human PECAM-1 antibodies directed against different linear epitopes of the extracellular domain have different effects on the mobilization of calcium in REN-HP cells. PECAM-1 is a modular protein with six extracellular Ig-like domains (20). To explore the functional aspects of the different extracellular regions of the PECAM-1 molecule, we stimulated cells with additional antibodies directed against various regions of the PECAM-1 molecule. The region of binding of each of these antibodies, as confirmed by flow cytometry and/or immunofluorescence staining of COS cells transfected with human/mouse chimeras, is shown in Table I.

Table I shows that four of the six antibodies tested induced an increase in $\left[\mathrm{Ca}^{2+}\right]_{i}$ in REN-HP cells. Interestingly, not all antibodies were capable of eliciting the rise in cytosolic calcium upon engagement of PECAM-1, despite being directed against the same extracellular Ig-like domain. Specifically, Fabs of mAbs 35 and 66, antibodies directed against Ig-like domain 1 , did not increase $\left[\mathrm{Ca}^{2+}\right]_{i}$ induced by Fabs of mAbs 37 and 62, antibodies that also recognized epitopes in the same domain. Moon-1, the antibody that induced calcium increases in Jurkat cells (19), and which recognizes Ig-like domain 2, was also able to stimulate the increase in $\left[\mathrm{Ca}^{2+}\right]_{\mathrm{i}}$ in REN-HP cells. These studies suggest that the calcium signals can be stimulated after engagement of some but not all regions of PECAM-1 in REN-HP cells.

Engagement of human PECAM-1 stimulates formation and secretion of $\mathrm{PGl}_{2}$ in HUVEC and REN-HP cells. To determine if increases in $\left[\mathrm{Ca}^{2+}\right]_{\mathrm{i}}$ induced by engagement of PECAM-1 led to measurable functional consequences, we assessed the ability of the anti-PECAM-1 antibody 4G6 to stimulate the secretion of $\mathrm{PGl}_{2}$ as measured by the secretion of its stable metabolite 6-keto PGF1 $\alpha$. Treatment of HUVEC (Fig. $8 A$ ) or REN-HP

Table I. Epitope Dependence of Ability of Human PECAM-1 to Evoke a $\mathrm{Ca}^{2+}$ Signal in REN-HP Cells

\begin{tabular}{lcc}
\hline Anti-human PECAM-1 mAb & $\begin{array}{c}\text { Location of binding epitope } \\
\text { (Ig-like domain) }\end{array}$ & $\begin{array}{c}\text { Net increase in } \\
{\left[\mathrm{Ca}^{2+}\right]_{\mathrm{i}}(\mathrm{nM})}\end{array}$ \\
\hline \#35 Fab (IgG $\gamma 1)$ & 1 & -* $^{*}$ \\
\#37 Fab (IgG $\gamma 1)$ & 1 & $111 \pm 10^{\ddagger}$ \\
\#62 Fab (IgG $\gamma 2 \mathrm{a})$ & 1 & $127 \pm 12^{\ddagger}$ \\
\#66 Fab (IgG $\gamma 1)$ & 1 & $-*$ \\
Moon-1 (intact) (IgG $\gamma 1)$ & 2 & $130 \pm 30^{\ddagger}$ \\
4G6 (intact and Fab) (IgG $\gamma 2 \mathrm{a})$ & 6 & $230 \pm 13^{\ddagger}$ \\
\hline
\end{tabular}

*(-) Net increase in $\left[\mathrm{Ca}^{2+}\right]$ induced by the mAb was no different from basal $\left[\mathrm{Ca}^{2+}\right] .{ }^{\ddagger} P<0.05$, basal $\left[\mathrm{Ca}^{2+}\right]$ vs. mAb stimulated $\left[\mathrm{Ca}^{2+}\right]_{\mathrm{i}}$ by Student's $t$ test. 
REN-HP

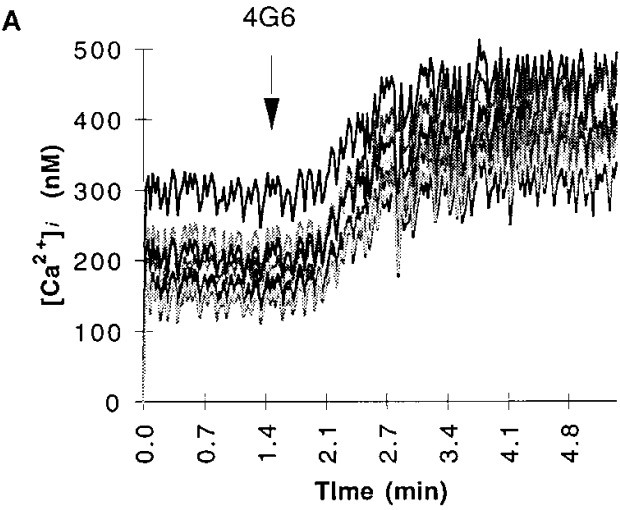

B

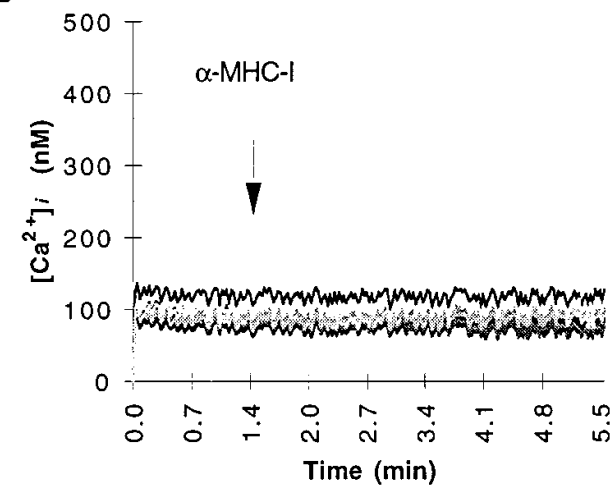

C

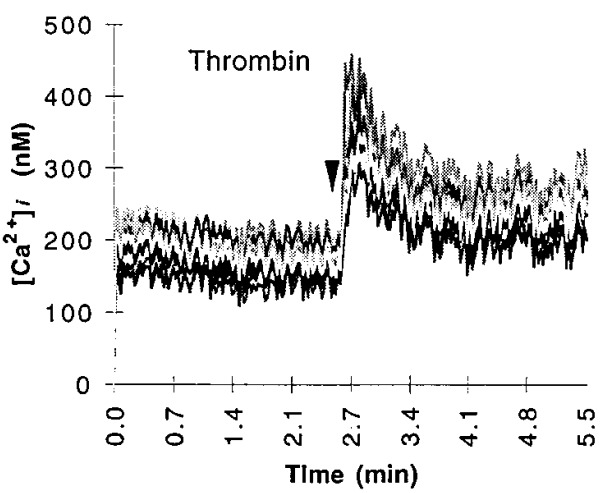

REN
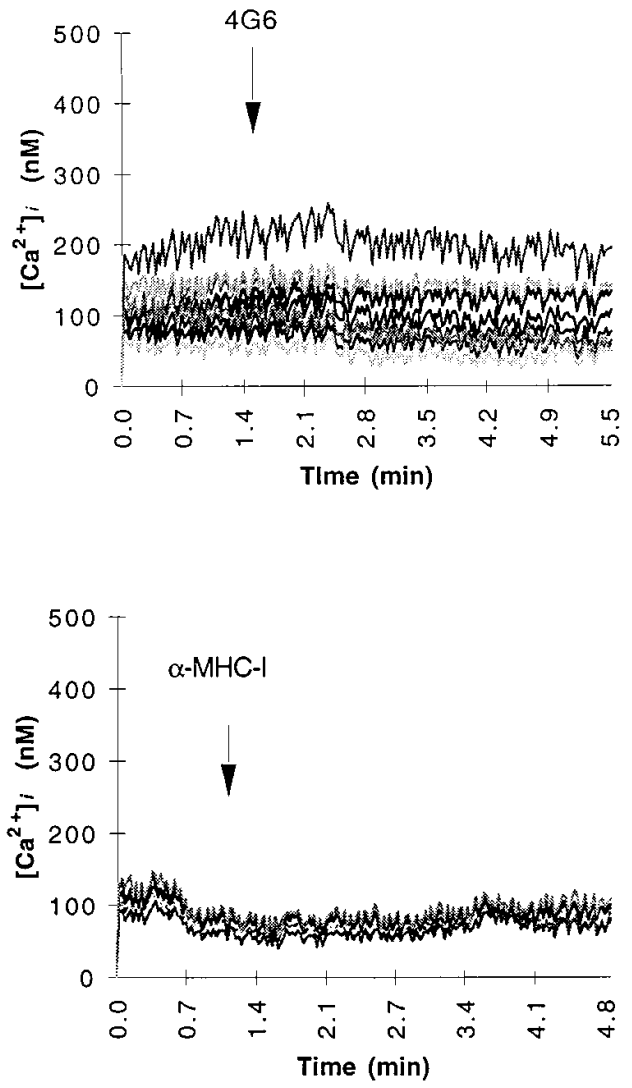

Figure 4. Activation of human PECAM-1 mediates $\left[\mathrm{Ca}^{2+}\right]_{\mathrm{i}}$ increase in transfected REN cells. REN cells were transfected with fulllength human PECAM-1 (REN-HP cells) as described in Methods. ( $A$ ) REN-HP cells (left) treated with 4G6 $(20 \mu \mathrm{g} / \mathrm{ml})$ increase $\left[\mathrm{Ca}^{2+}\right]_{\text {, }}$, but untransfected REN cells (right) do not. (B) In contrast, application of antiMHC-I mAb has little effect on cytosolic free calcium in REN-HP cells or untransfected REN cells. $(C)$ Both REN-HP and REN cell lines respond to thrombin $(1 \mathrm{U} / \mathrm{ml})$ with increases in $\left[\mathrm{Ca}^{2+}\right]_{\mathrm{i}}$ which is similar in time course to HUVEC and is different from that observed with $4 \mathrm{G} 6$. Each trace represents the response of a single cell, and a minimum of 10 cells was included in each experiment. The data shown are representative of a minimum of three separate experiments. cells (Fig. $8 \mathrm{~B}$ ) with either 4G6 antibody or thrombin induced secretion of 6-keto PGF1 $\alpha$ into supernatants as measured by gas chromatography/mass spectrometry. The response was maximal at $10 \mathrm{~min}$ and reached a plateau at $15 \mathrm{~min}$. Although MHC-I is expressed at high levels on the cell surface of HUVEC, REN-HP cells and REN cells, administration of an antiMHC-I mAb had no effect on $\mathrm{PGl}_{2}$ secretion. Specificity of this response was determined in untransfected REN cells that do not express PECAM-1. As shown in Fig. 8 C, 4G6 treatment of these cells had little effect on $\mathrm{PGl}_{2}$ secretion despite a positive response to thrombin.
To examine whether increases in cytosolic calcium modulate 4G6-induced $\mathrm{PGl}_{2}$ secretion in HUVEC, cells were pretreated with EGTA or nickel and $\mathrm{PGl}_{2}$ levels were then measured in the supernatants. Both nickel and EGTA pretreatment completely abrogated 4G6-induced $\mathrm{PGl}_{2}$ secretion as shown in Fig. $8 \mathrm{D}$. In parallel experiments, pretreatment of HUVEC with genistein, a tyrosine kinase inhibitor, also blocked 4G6-induced secretion of $\mathrm{PGl}_{2}$ (Fig. $8 \mathrm{D}$ ). Taken together, these data suggest that activation of PECAM-1 stimulates $\mathrm{PGl}_{2}$ secretion that is dependent on extracellular calcium and on tyrosine phosphorylation. 

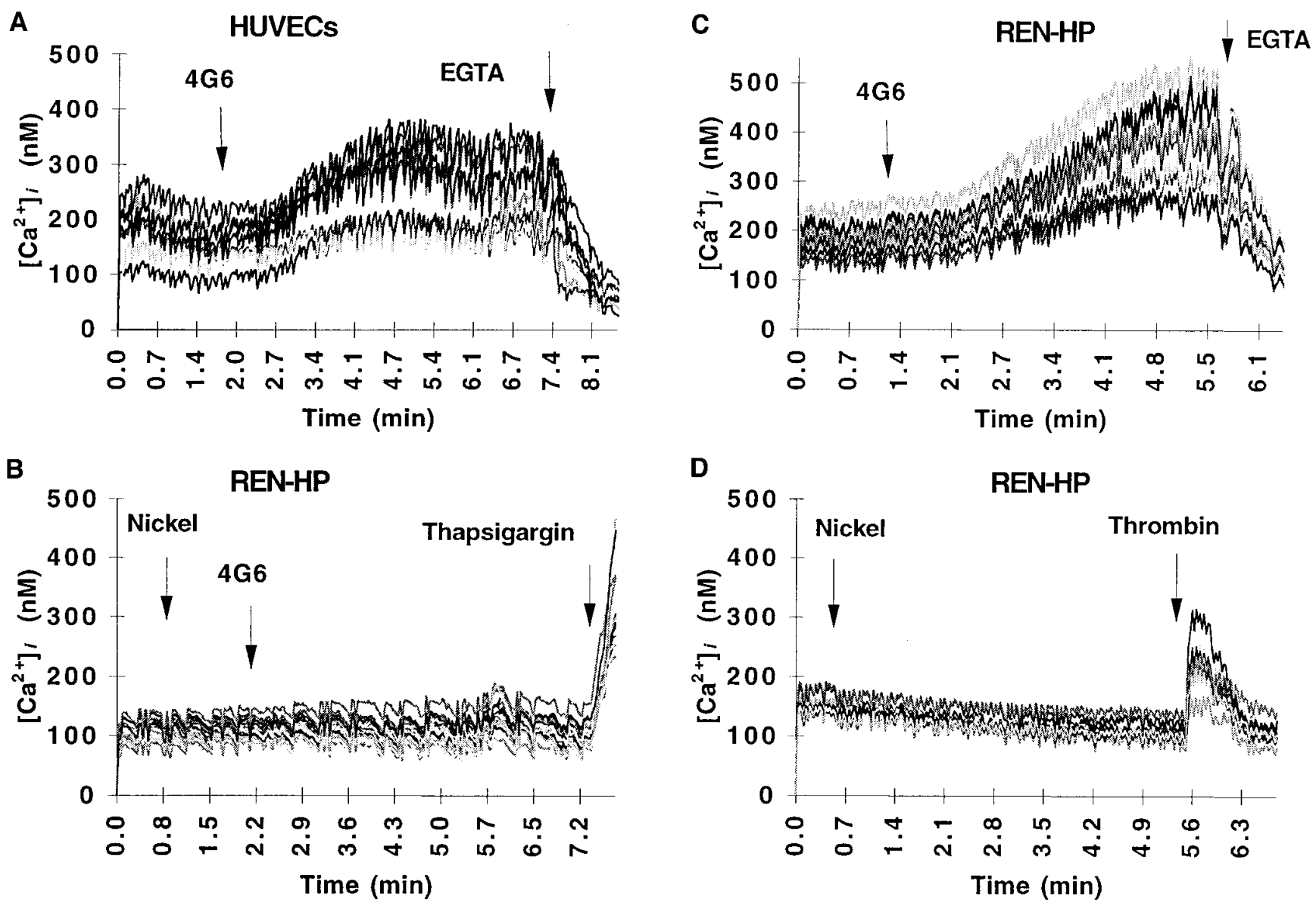

Figure 5. Extracellular calcium mediates PECAM-1-evoked increases in $\left[\mathrm{Ca}^{2+}\right]_{\mathrm{i}}$. Both in HUVEC $(A)$ and in REN-HP cells $(B)$, the PECAM1 -mediated rise in $\left[\mathrm{Ca}^{2+}\right]_{\mathrm{i}}$ is abolished by adding EGTA $(5 \mathrm{mM})$ during the sustained phase or after pretreatment with nickel $(4 \mathrm{mM})(C$ and $D)$. Nickel did not inhibit the calcium response to either thrombin $(1 \mathrm{U} / \mathrm{ml})$ or thapsigargin $\left(10^{-7} \mathrm{M}\right)$. Each trace represents the response of a single cell, and a minimum of 10 cells was included in each experiment. These data are representative of a minimum of three separate experiments.

\section{Discussion}

Although PECAM-1 was initially characterized as a cell-cell adhesion molecule, evidence is accumulating that this molecule, like many other cell adhesion molecules, also serves a signaling function $(17,18)$. These data indicate that engagement of PECAM-1 by anti-PECAM-1 antibodies can induce activation of $\beta_{1}$ integrins on human T cells (34) and $\beta 2$ integrins on LAK cells, neutrophils, monocytes, and natural killer cells (15, 35), as well as on platelets (36).

Our experiments suggest an additional, novel signaling role for PECAM-1 in ECs. Using single-cell calcium fluorometry with fura-2/AM, we found that engagement of PECAM-1 by antibodies resulted in a slow but sustained increase in $\left[\mathrm{Ca}^{2+}\right]_{\mathrm{i}}$ in both ECs and in an adherent, PECAM-1-transfected cell line that models endothelium. The calcium increase was associated with at least one functionally important consequence: the generation of $\mathrm{PGl}_{2}$. Generation of this signal was specific for certain anti-PECAM-1 antibodies and required the presence of the cytoplasmic domain, but unlike integrin activation, did not require cross-linking.

To confirm the specificity of our observations and to exclude the possibility that the responses were due to nonspecific cell surface-antibody binding or $F_{c}$ receptor activation, we con- ducted a number of control experiments. Evidence against our observations being nonspecific responses included lack of calcium increases or $\mathrm{PGl}_{2}$ formation after application of an antiMHC-I mAb that bound at high levels to the surface of HUVEC (Fig. 2 B), strong responses on HUVEC after use of Fab fragments (data not shown), and increases in calcium after treatment with multiple anti-PECAM-1 antibodies.

To conduct additional control experiments and to study the mechanisms involved in PECAM-1-mediated calcium increases and cellular activation from a molecular standpoint, we created a model EC line consisting of human mesothelioma (REN) cells transfected with human PECAM-1. REN cells bear morphologic and functional resemblance to ECs, inducibly express ICAM-1 and VCAM-1 and, when transfected, express PECAM-1 at intercellular borders (Fig. 3) in a stable, constitutive fashion (Fig. 1). The calcium transients observed in transfected REN cells after anti-PECAM-1 mAbs and after application of thrombin were similar in magnitude and time course when compared to HUVEC (compare Fig. 2 with Fig. 4). Similar results were obtained when $\mathrm{PGl}_{2}$ was assayed (Fig. 8). Like our findings in HUVEC, application of the antiMHC-I antibody had no effect on calcium levels or $\mathrm{PGl}_{2}$ for- 


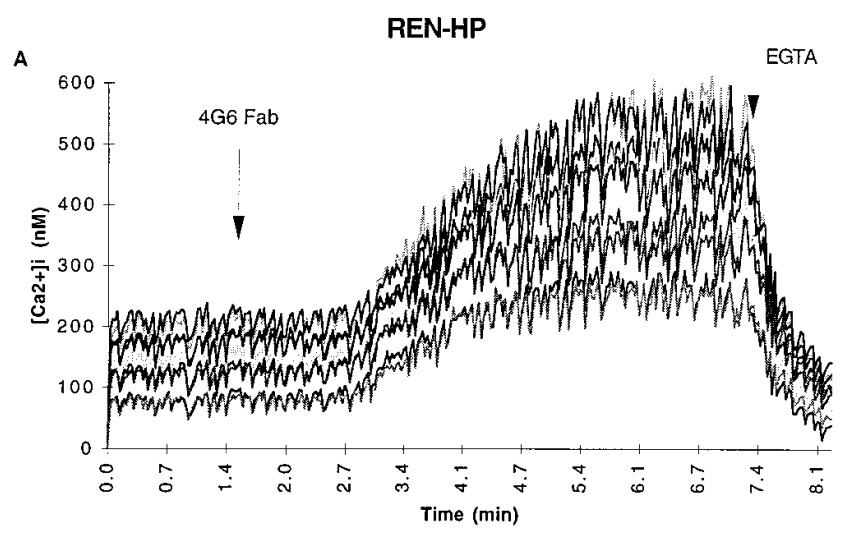

REN

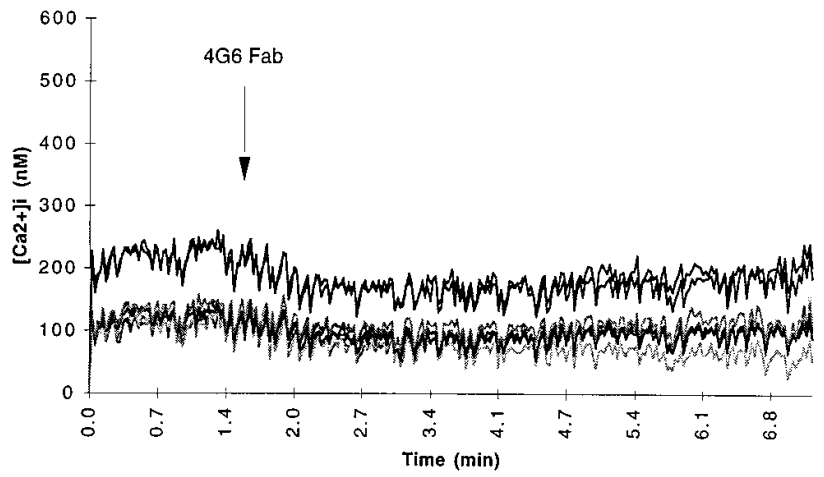

Figure 6. Engagement of human PECAM-1 with $4 \mathrm{G} 6 \mathrm{Fab}$ in REN cells is sufficient to increase $\left[\mathrm{Ca}^{2+}\right]_{\mathrm{i}} .(A)$ Treatment of REN-HP cells with purified $4 \mathrm{G} 6 \mathrm{Fab}$ increases $\left[\mathrm{Ca}^{2+}\right]_{\mathrm{i}}$. $(B)$ In contrast, treatment of untransfected REN cells with 4G6 Fab has little effect on $\left[\mathrm{Ca}^{2+}\right]_{\mathrm{i}}$.

Each trace represents an individual cell response, and a minimum of 10 cells was included in each experiment. These data are representative of a minimum of two separate experiments.

mation in REN cells. More importantly, significant calcium responses were generated in the REN cells transfected with human PECAM-1 (REN-HP cells) treated with 4G6 but not in the parental cell lines lacking PECAM-1. Another result that argues against any nonspecific effects of the anti-PECAM-1 $\mathrm{mAb}$ is the fact that after treatment with antibody, cells expressing the mutant PECAM-1 molecule lacking the cytoplasmic domain of human PECAM-1 (REN-CDM2 cells) did not show an increase in calcium (Fig. 7), despite the fact that the antibody bound at high levels to these cells (Fig. $1 G$ ). This experiment also demonstrated that the cytoplasmic region of PECAM-1 is necessary for signal transduction.

The mechanism by which engagement of PECAM-1 augments $\left[\mathrm{Ca}^{2+}\right]_{\mathrm{i}}$ and $\mathrm{PGl}_{2}$ formation is not yet known; however, our data suggest several important clues. Most of the wellstudied EC activating agents such as thrombin (see Figs. $2 C$ and $4 \mathrm{C}$ ), histamine, and bradykinin evoke a rapid, large response reached within 20-30 s, followed by a prolonged phase of calcium elevation that persists for 5-8 min (for review see reference 2). The initial calcium spike is thought to be due to receptor coupling to $\mathrm{G}$ proteins that activate specific phospho-
REN-CDM2

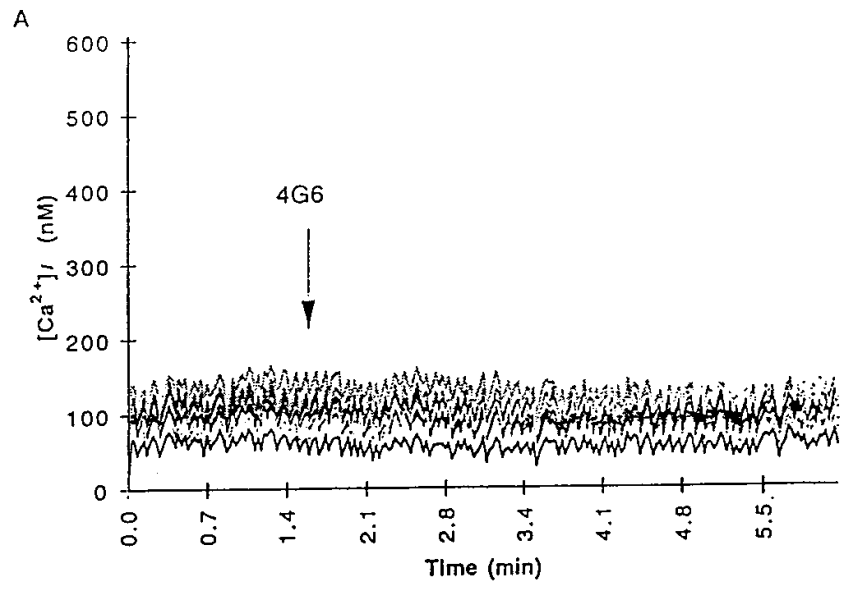

B
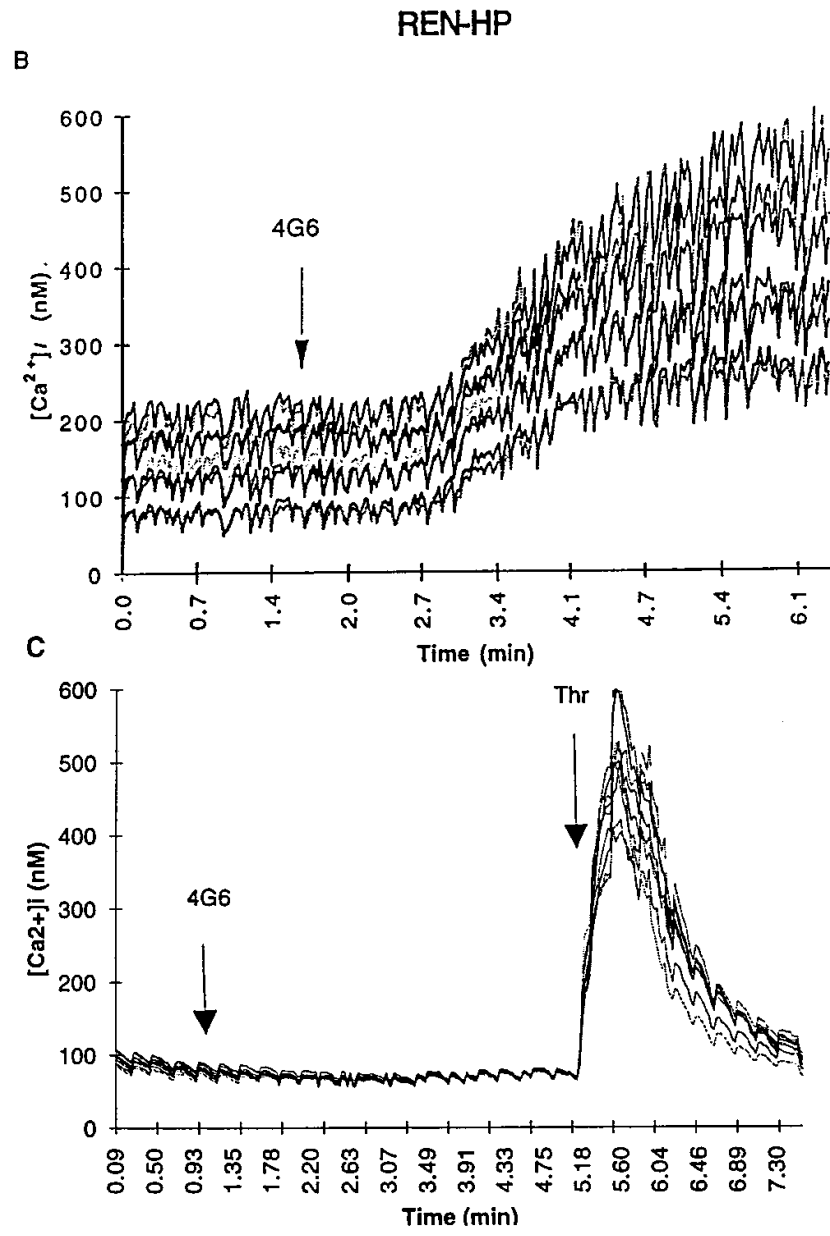

Figure 7. The cytoplasmic domain of PECAM-1 and tyrosine phosphorylation are required for induction of calcium influx upon PECAM-1 engagement. ( $A$ ) REN-CDM2 cells, which express a mutant form of PECAM-1 lacking the cytoplasmic domain, fail to experience calcium influx after PECAM-1 engagement with mAb 4G6.

(B) In contrast, REN-HP cells treated with the same dose of 4G6 antibody do exhibit a calcium response. Binding of $4 \mathrm{G} 6$ to REN-CDM2 cells was confirmed by flow cytometry, as depicted in Fig. $1 G$. $(C)$ $\mathrm{Ca}^{2+}$ mobilization induced after PECAM-1 stimulation is inhibited by genistein treatment in REN-HP cells. Cells were pretreated with genistein $(10 \mu \mathrm{M}, 1 \mathrm{~h})$ and then stimulated with $4 \mathrm{G} 6(20 \mu \mathrm{g} / \mathrm{ml})$ and thrombin $(1 \mathrm{U} / \mathrm{ml})$. These traces are representative of three separate experiments. 
A

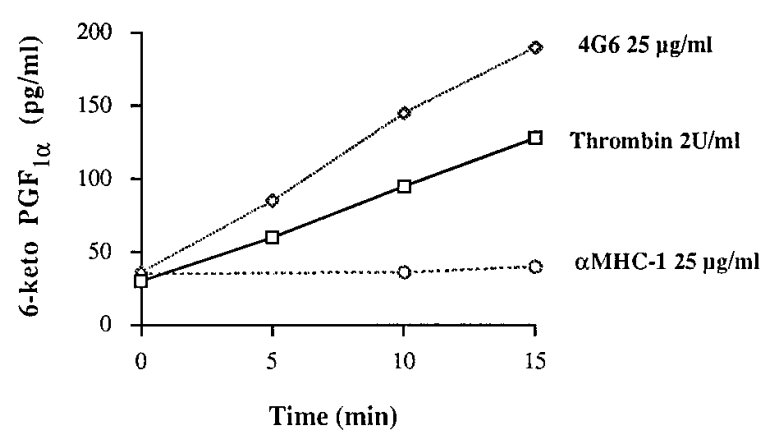

B

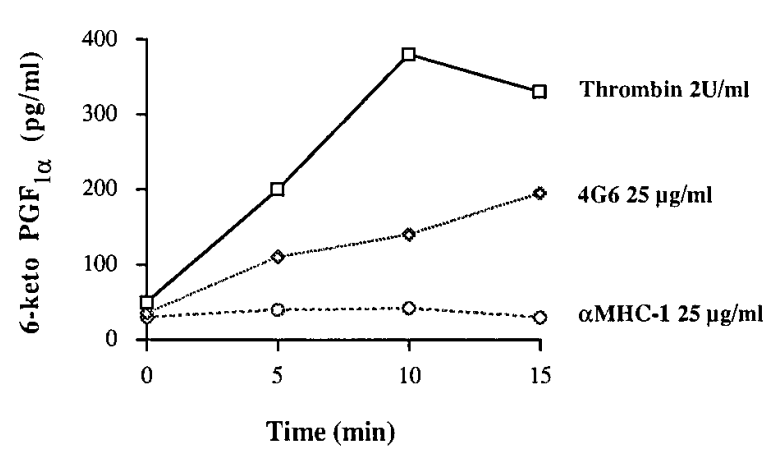

C

REN Cells

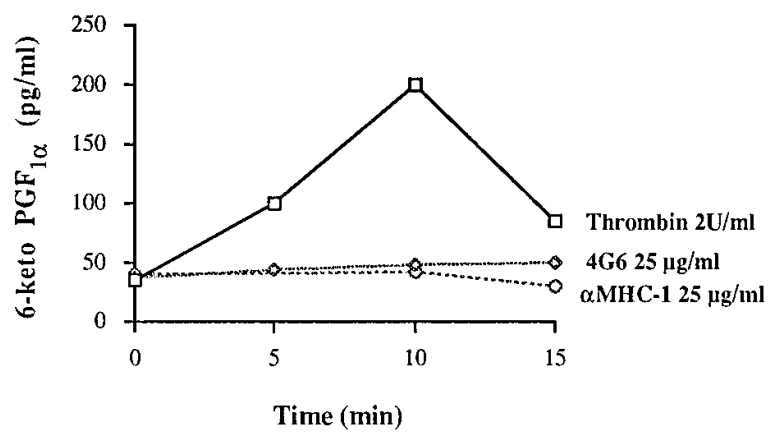

D

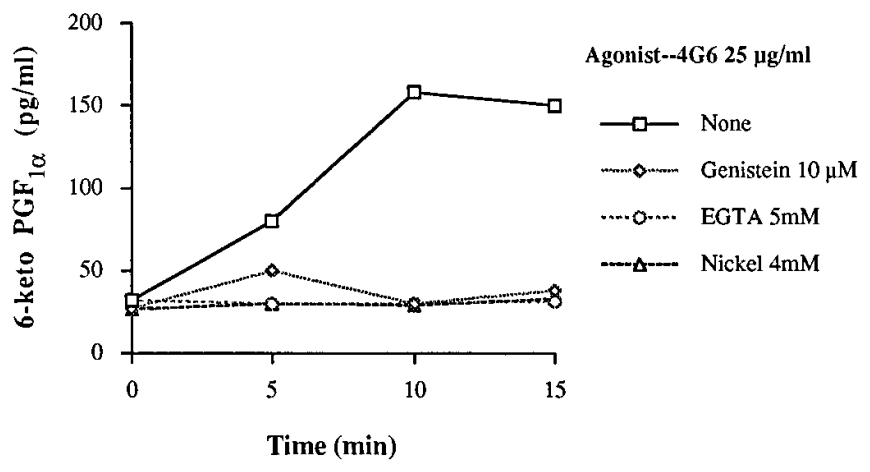

Figure 8. Engagement of human PECAM-1 stimulates formation and secretion of $\mathrm{PGl}_{2}$ in HUVEC and REN-HP cells. Treatment of REN-HP $(A)$ or HUVEC cells $(B)$ with either 4G6 antibody or thrombin induced secretion of $\mathrm{PGl}_{2}$ into supernatants as measured by its stable metabolite 6-keto PGF1 $\alpha$ using gas chromatography/mass spectrometry. In contrast, treatment of cells with an anti-MHC-I antibody had no effect on PGl secretion. 4G6 treatment of untransfected REN cells not expressing PECAM-1 $(C)$ had little effect on $\mathrm{PGl}_{2}$ secretion. This experiment was repeated once with data virtually identical to the data shown here. To address whether extracellular calcium or tyrosine phosphorylation mediates 4G6-induced $\mathrm{PGl}_{2}$ secretion in $\operatorname{HUVEC~}(D)$, cells were pretreated with either genistein $(10 \mu \mathrm{M})$, EGTA $(5 \mathrm{mM})$, or nickel $(4 \mathrm{mM})$ and PGl 2 secretion measured. Nickel or EGTA pretreatment abolished 4G6-induced $\mathrm{PGl}_{2}$ secretion, which suggests that $\mathrm{PGl}_{2}$ secretion induced by PECAM-1 is dependent on extracellular calcium. Inhibition of PECAM-1-induced $\mathrm{PGl}_{2}$ secretion by genistein suggests that the tyrosine phosphorylation may play a role in regulating PECAM-1-induced $\mathrm{PGl}_{2}$ secretion.

lipase $\mathrm{C}$ isoenzymes with subsequent release of $\mathrm{IP}_{3}$ and release of internal calcium stores. The influx of extracellular calcium, which constitutes the delayed component, is still poorly understood. The slower, more prolonged elevation in calcium seen after PECAM-1 engagement is similar to that seen after crosslinking of other immunoglobulin superfamily members (such as the T cell receptor [37], ICAM-3 [38], and neural cell adhesion molecule L1 [39]) suggesting that the sequence of events which occur from engagement of PECAM-1 to the influx of calcium ions into the cell is distinct from the pathway which occurs upon thrombin application. This is supported by the observations that the sustained increase induced by 4G6 was abolished when REN-HP cells and HUVEC were placed in nominally calcium-free or by pretreating cells with nickel, a treatment that has been shown previously to block calcium influx into ECs (40-42). Taken together, these results strongly suggest that the sustained increase in $\left[\mathrm{Ca}^{2+}\right]_{\mathrm{i}}$ after PECAM-1 activation is due to influx of extracellular calcium.

The complete inhibition of calcium responses mediated by 4G6 by the tyrosine kinase inhibitor, genistein, suggests that tyrosine phosphorylation is coupled to this process. Although there are always potential nonspecific effects seen with inhibi- tors, these data are consistent with the notion that one or more tyrosine kinases could play an important role in the calcium signaling mediated by adhesion molecules. Juan et al. (38) found that activation of ICAM-3 (CD50) by specific antibodies also induced calcium mobilization in Jurkat $\mathrm{T}$ cells which, like 4G6, also required calcium from extracellular medium and tyrosine phosphorylation. How these adhesion molecules, and in particular PECAM-1, activate or interact with tyrosine kinases remains an area of ongoing investigation. It is possible that PECAM-1 itself is phosphorylated. Although the cytoplasmic domain of PECAM-1 has no intrinsic kinase activity and is not capable of autophosphorylation, tyrosine residues in the cytoplasmic domain of PECAM-1 can be phosphorylated in ECs (43). Subsequently, at least in platelets, one or more of these sites is capable of docking an $\mathrm{SH} 2$ domain of the protein tyrosine phosphatase (SHP-2) (36). SHP-2 also serves as a docking protein which could, in turn, mediate one of many downstream signaling events which could lead to increases in $\left[\mathrm{Ca}^{2+}\right]_{i}$. Defining the exact regions of the cytoplasmic domain responsible for calcium signaling is beyond the scope of this study, but experiments are in progress using mutant PECAM-1 molecules, including one containing the mutation of tyrosine ${ }_{663}$ 
to phenylalanine to study the importance of phosphorylation of this particular tyrosine residue.

In addition to understanding how the cytoplasmic domain of PECAM-1 may regulate calcium influx, the role of extracellular regions of PECAM-1 in calcium signaling needs to be defined more clearly. Our data suggest that engagement of PECAM-1, not cross-linking, is required for calcium signaling. Furthermore, the interaction has specificity, as some but not all anti-PECAM-1 Fabs that recognize a given extracellular loop can induce increases in calcium (Table I). Engagement may induce a specific conformational change that mimics ligand binding, promotes dimerization, or changes in PECAM1 's interaction with cytoplasmic proteins. Since the identity of ligands which bind PECAM-1 and the mechanisms that regulate binding specificity are still not well characterized, defining which PECAM-binding ligands trigger calcium influx will be difficult. At this time, we do not know whether heterophilic PECAM-1 interactions or homophilic PECAM-PECAM interactions serve as physiologic regulators of calcium signaling. The use of PECAM-1- $\mathrm{IgF}_{\mathrm{c}}$ chimeras (44) or experiments that take advantage of the fact that human and mouse PECAM-1 do not interact in a homophilic manner will be useful in trying to answer these questions.

As discussed above, the PECAM-1-induced increases in $\left[\mathrm{Ca}^{2+}\right]_{\mathrm{i}}$ could have a number of important physiologic effects. In these experiments, we have directly measured $\mathrm{PCl}_{2}$ secretion as an example of one known physiological consequence of increased EC $\left[\mathrm{Ca}^{2+}\right]_{\mathrm{i}}$. Another area where we speculate that PECAM-1-induced increases in EC $\left[\mathrm{Ca}^{2+}\right]$ might have important effects is in the regulation of leukocyte transendothelial migration. Given the observations that antibodies against PECAM-1 block neutrophil and monocyte transmigration in vitro and in vivo $(13,16)$ and that increases in EC free calcium appear to be required for neutrophil transmigration across monolayers of EC, it is tempting to hypothesize that during leukocyte-EC interactions, engagement of PECAM-1 at the appropriate time on the EC leads to the increase in free calcium levels that is required for successful transmigration. We are currently testing this hypothesis.

In summary, these studies have identified a potential new signaling pathway in ECs that is mediated by the vascular adhesion molecule PECAM-1. The role of this pathway in transmigration and its potential role in other cell types that express PECAM-1, such as neutrophils and monocytes, remain to be determined. A better understanding of this process may offer new therapeutic approaches in a number of inflammatory conditions.

\section{Acknowledgments}

The authors wish to thank Dr. Marian Nakada (Centocor) and Dr. Fabio Malavasi (Torino, Italy) for provision of antibodies, Ms. Mildred Daise for assistance with antibody purification and production, and Drs. Kunjilata Amin, Jing Sun, and Horace DeLisser for assistance with epitope mapping. We also gratefully appreciate Mr. Christopher Maki's help with $\mathrm{Ca}^{2+}$ measurements. Our sincere thanks to Ms. Mary McNichol for assistance in the preparation of the manuscript.

This work was supported by National Institutes of Health grants HL46311 (to Dr. Albelda) and R01-HL55301 (to Dr. Panettieri), NASA NRA-94-OLMSA-02 (to Dr. Panettieri), and a Career Investigator Award from the American Lung Association (to Dr. Panettieri). Dr. Yassine Amrani was supported by a postdoctoral fellow- ship of the Association Française pour la Recherche Thérapeutique (AFRT), Paris. Frederick L. Ruberg is a Howard Hughes Medical Institute Medical Student Research Training Fellow.

\section{References}

1. Graier, W.F., M. Sturek, and W.R. Kukovetz. 1994. Calcium regulation and endothelial vascular function. Endothelium. 1:223-236.

2. Himmel, H.M., A.R. Whorton, and H.C. Strauss. 1993. Intracellular calcium, currents, and stimulus-response coupling in endothelial cells. Hypertension. 21:112-127.

3. Hattori, R., K.K. Hamilton, R.D. Fugate, R.P. McEver, and P.J. Sims. 1989. Stimulated secretion of endothelial von Willebrand factor is accompanied by rapid redistribution to the cell surface of the intracellular granule membrane protein GMP-140. J. Biol. Chem. 264:7768-7771.

4. Bennett, J., and A. Weeds. 1986. Calcium and the cytoskeleton. Br. Med. Bull. 42:385-390.

5. Lum, H., P.J. del Vecchio, A.S. Schneider, M.S. Goligorsky, and A.B. Malik. 1989. Calcium dependence of the thrombin-induced increase in endothelial albumin permeability. J. Appl. Physiol. 66:1471-1476.

6. Lum, H., and A.B. Malik. 1994. Regulation of vascular endothelial barrier function. Am. J. Physiol. 267:L223-L241.

7. Wysolmerski, R.B., and D. Lagunoff. 1990. Involvement of myosin lightchain kinase in endothelial cell retraction. Proc. Natl. Acad. Sci. USA. 87:16-20.

8. He, P., S.M. Pogakis, and F.E. Curry. 1990. Measurement of cytoplasmic calcium in single microvessels with increased permeability. Am. J. Physiol. 258: H1366-H1374.

9. Huang, A.J., J.E. Manning, T.M. Bandak, M.C. Tatau, K.R. Hanser, and S.C. Silverstein. 1993. Endothelial cell cytosolic free calcium regulates neutrophil migration across monolayers of endothelial cells. J. Cell Biol. 120:13711380 .

10. Schimmenti, L.A., H.C. Yan, J.A. Madri, and S.M. Albelda. 1992. Platelet-endothelial cell adhesion molecule, PECAM-1, modulates cell migration. $J$. Cell Physiol. 153:417-428.

11. DeLisser, H.M., M. Christofidou-Solomidou, R.M. Strieter, M.D. Burdick, C.S. Robinson, R.S. Wexler, J.S. Kerr, C. Garlanda, J. Merwin, J. Madri, et al. 1997. Involvement of endothelial PECAM-1/CD31 in angiogenesis. Am. J. Pathol. 151:671-677.

12. Ferrero, E., M.E. Ferrero, R. Pardi, and M.R. Zocchi. 1995. The platelet endothelial cell adhesion molecule-1 (PECAM1) contributes to endothelial barrier function. FEBS Lett. 374:323-326.

13. Muller, W.A., S.A. Weigl, X. Deng, and D.M. Phillips. 1993. PECAM-1 is required for transendothelial migration of leukocytes. J. Exp. Med. 178:449460.

14. Poggi, A., M.C. Panzeri, L. Moretta, and M.R. Zocchi. 1996. CD31-triggered rearrangement of the actin cytoskeleton in human natural killer cells. Eur. J. Immunol. 26:817-824.

15. Berman, M.E., Y. Xie, and W.A. Muller. 1996. Roles of platelet/endothelial cell adhesion molecule-1 (PECAM-1, CD31) in natural killer cell transendothelial migration and $\beta_{2}$, integrin activation. J. Immunol. 156:15151524.

16. Vaporicyan, A.A., H.M. DeLisser, H.C. Yan, I.I. Mendiguren, S.R. Thom, M.L. Jones, P.A. Ward, and S.M. Albelda. 1993. Involvement of platelet-endothelial cell adhesion molecule-1 in neutrophil recruitment in vivo. Science. 262:1580-1582.

17. DeLisser, H.M., P.J. Newman, and S.M. Albelda. 1994. Molecular and functional aspects of PECAM-1/CD31. Immunol. Today. 15:490-495.

18. Newman, P.J. 1997. The biology of PECAM-1. J. Clin. Invest. 99:3-8.

19. Deaglio, S., U. Dianzai, A.L. Horenstein, J.E. Fernandez, C. van Kooten, M. Bragardo, A. Funaro, G. Garbarino, F. Di Virgilio, J. Banchereau, et al. 1996. Human CD38 ligand. A 120-KDA protein predominantly expressed on endothelial cells. J. Immunol. 156:727-734.

20. Yan, H.C., J.M. Pilewski, Q. Zhang, H.M. DeLisser, L. Romer, and S.M. Albelda. 1995. Localization of multiple functional domains on human PECAM-1 (CD31) by monoclonal antibody epitope mapping. Cell Adhes. Commun. 3:4566.

21. Albelda, S.M., W.A. Muller, C.A. Buck, and P.J. Newman. 1991. Molecular and cellular properties of PECAM-1 (endoCAM/CD31): a novel vascular cell-cell adhesion molecule. J. Cell Biol. 114:1059-1068.

22. Albelda, S.M., M. Daise, E.M. Levine, and C.A. Buck. 1989. Identification and characterization of cell-substratum adhesion receptors on cultured human endothelial cells. J. Clin. Invest. 83:1992-2002.

23. Smythe, W.R., H.C. Hwang, K.M. Amin, S.L. Eck, B.L. Davidson, J.M. Wilson, L.R. Kaiser, and S.M. Albelda. 1994. Use of recombinant adenovirus to transfer the herpes simplex virus thymidine kinase (HSVTk) gene to thoracic neoplasms: an effective in vitro drug sensitization system. Cancer Res. 54:20552059.

24. Sambrook, J., E.F. Fritsch, and T. Maniatis. 1989. Molecular Cloning: A Laboratory Manual. 2nd ed. Cold Spring Harbor Laboratory, Cold Spring Harbor, NY. 545 pp. 
25. DeLisser, H.M., J. Chilkotowsky, H.C. Yan, M.L. Daise, C.A. Buck, and S.M. Albelda. 1994. Deletions in the cytoplasmic domain of platelet-endothelial cell adhesion molecule (PECAM-1, CD31) result in changes in ligand binding properties. J. Cell Biol. 124:195-203.

26. Sun, J., J. Williams, H.C. Yan, K.M. Amin, S.M. Albelda, and H.M. DeLisser. 1996. Platelet endothelial cell adhesion molecule-1 (PECAM-1) homophilic adhesion is mediated by immunoglobulin-like domains 1 and 2 and depends on the cytoplasmic domain and the level of surface expression. J. Biol. Chem. 271:18561-18570.

27. Panettieri, R.A., Jr., I.P. Hall, C.S. Maki, and R.K. Murray. 1995. $\alpha$-thrombin increases cytosolic calcium and induces human airway smooth muscle cell proliferation. Am. J. Respir. Cell Mol. Biol. 13:205-216.

28. Grynkiewicz, G., M. Poenie, and R.Y. Tsien. 1985. A new generation of $\mathrm{Ca}^{2+}$ indicators with greatly improved fluorescence properties. J. Biol. Chem. 260:3440-3450.

29. Pratico, D., J.A. Lawson, and G.A. FitzGerald. 1995. Cyclooxygenasedependent formation of the isoprostane, 8-epi prostaglandin F2 alpha. J. Biol. Chem. 270:9800-9808.

30. Pollack, W.K., K.A. Wreggett, and R.G. Irvine. 1988. Inositol phosphate production and $\mathrm{Ca}^{2+}$ mobilization in human umbilical-vein endothelial cells stimulated by thrombin and histamine. Biochem. J. 256:371-376.

31. Ryan, U.S., P.V. Avdonin, E.Y.A. Posin, E.G., Popov, S.M. Danilov, and V.A. Tkachuk. 1988. Influence of vasoactive agents on cytoplasmic free calcium in vascular endothelial cells. J. Appl. Physiol. 65:2221-2227.

32. Birch, K.A., B.M. Ewenstein, D.E. Golan, and J.S. Pober. 1994. Prolonged peak elevations in cytoplasmic free calcium ions, derived from intracellular stores, correlate with the extent of thrombin-stimulated exocytosis in single human umbilical vein endothelial cells. J. Cell Physiol. 160:545-554.

33. Muller, W.A., and S.A. Weigl. 1992. Monocyte-selective transendothelial migration: dissection of the binding and transmigration phases by an in vitro assay. J. Exp. Med. 176:819-828.

34. Jackson, D.E., C.M. Ward, R. Wang, and P.J. Newman. 1997. The pro- tein tyrosine phosphatase, SHP-2, binds PECAM-1 and forms a distinct signaling complex during platelet aggregation. Evidence for a mechanistic link between PECAM-1 and integrin-mediated cellular signaling. J. Biol. Chem. 272: 6986-6993.

35. Spinozzi, F., E. Agea, O. Bistoni, S. Belia, A. Travetti, R. Gerli, C. Muscat, and A. Bertotto. 1995. Intracellular calcium levels are differentially regulated in T lymphocytes triggered by anti-CD2 and anti-CD3 monoclonal antibodies. Cell. Signal. 7:287-293.

36. Juan, M., O. Vinas, M.R. Pino-Otin, L. Places, E. Martinez-Caceres, J.J. Barcelo, A. Miralles, R. Vilella, M.A. de la Fuente, J. Vives, et al. 1994. CD50 (intercellular adhesion molecule 3) stimulation induces calcium mobilization and tyrosine phosphorylation through $\mathrm{p} 59^{\mathrm{fyn}}$ and $\mathrm{p} 56^{\mathrm{lck}}$ in Jurkat $\mathrm{T}$ cell line. $J$. Exp. Med. 179:1747-1756.

37. Itoh, K., H. Kawamura, and H. Asou. 1992. A novel monoclonal antibody against carbohydrates of L1 cell adhesion molecule causes an influx of calcium in cultured cortical neurons. Brain Res. 580:233-240.

38. Hallam, T.J., R. Jacob, and J.E. Merritt. 1988. Evidence that agonists stimulate bivalent-cation influx into human endothelial cells. Biochem. J. 255: 179-184.

39. Buchan, K.W., and W. Martin. 1991. Bradykinin induces elevations of cytosolic calcium through mobilisation on intracellular and extracellular pools in bovine aortic endothelial cells. Br. J. Pharmacol. 102:35-40.

40. Dolor, R.J., L.M. Hurwitz, Z. Mirza, H.C. Strauss, and A.R. Whorton. 1992. Regulation of extracellular $\mathrm{Ca}^{2+}$-entry in endothelial cells. Role of intracellular calcium pool. Am. J. Physiol. 262:C171-C181.

41. Lu, T.T., L.G. Yan, and J.A. Madri. 1996. Integrin engagement mediates tyrosine dephosphorylation on platelet-endothelial cell adhesion molecule 1. Proc. Natl. Acad. Sci. USA. 93:11808-11813.

42. Sun, Q.H., H.M. DeLisser, M.M. Zukowski, C. Paddock, S.M. Albelda, and P.J. Newman. 1996. Individually distinct Ig-homology domains in PECAM-1 regulate homophilic binding and modulate receptor affinity. J. Biol. Chem. 271: 11090-11098. 